\title{
磁性流体の界面現象を利用したマイクロ絞り機構の開発
}

\author{
須藤 誠一 ${ }^{* 1}$, 中西 将人 ${ }^{* 2}$, 篠㟝 成大 ${ }^{* 3}$, 西山 秀哉 ${ }^{* 4}$
}

\section{Development of micro diaphragm mechanism using surface phenomenon of magnetic fluid}

\author{
Seiichi SUDO ${ }^{* 1}$, Masato NAKANISHI ${ }^{* 2}$, Michihiro SHINOZAKI ${ }^{* 3}$ and Hideya NISHIYAMA*4 \\ ${ }^{{ }_{1},{ }^{*},{ }^{*}{ }_{3}}$ Faculty of Systems Science and Technology, Akita Prefectural University \\ 84-4Ebinokuchi, Yurihonjo-shi, Akita 015-0055, Japan \\ ${ }^{* 4}$ Institute of Fluid Science, Tohoku University \\ 2-1-1 Katahira, Aoba-ku, Sendai 980-8577, Japan
}

Received 30 September 2014

\begin{abstract}
This paper is concerned with the development of magnetic fluid micro devices. Liquid responses of a magnetic fluid adsorbed on a ring-shaped permanent magnet subject to alternating magnetic fields were investigated. The magnetic fluid adsorbed on the permanent magnet forms a hole, and the diameter of magnetic hole may be changed by external magnetic fields. Frequency characteristics of micro diaphragm mechanism based on the magnetic fluid-permanent magnet element system were examined experimentally. Liquid surface responses of the magnetic fluid were examined over the wide frequency range. It was revealed that the frequency of the liquid surface motion corresponds to the frequency of external alternating magnetic field. The magnetic field distributions around the element system were also measured, and relations between the magnetic field distribution and magnetic fluid surface motion were discussed. Furthermore, the improved model of the magnet-magnetic fluid element was produced, and its driving characteristics were obtained experimentally.
\end{abstract}

Key words : Magnetic fluids, Diaphragm mechanism, Interfacial phenomena, Magnetic fields, Permanent magnet, Harmonic liquid motions

\section{1. 緒訔}

磁性流体は，マグネタイト，鉄，コバルト，ニッケルなどの強磁性体の微粒子を，水，炭化水素，ジエステル などの溶媒中に高密度に分散させたコロイド溶液であり, 磁性と流動性を合わせ持つ人工流体である (Rosensweig, 1985）。磁性流体の自由表面は磁場の作用によってさまざまな界面現象を示す．たとえば，磁性流体プールが界面 に垂直な方向の磁場の作用を受けると Rosensweig 不安定性が誘起され，界面に多数のスパイクが生成される

(Cowley and Rosensweig, 1967). 疑似的な 2 次元矩形容器内の磁性流体が磁場の作用を受けると，界面は櫛形不 安定性を呈する（Sudo, et al., 1987）。また，磁性流体液滴が磁場の作用を受けると，磁場の方向に伸長する（Sudo, et al., 1989, Afkhami, et al., 2010). さらに，平板上の磁性流体液滴が静磁場および鉛直方向の振動場を受けると， ボンド数，振動ボンド数および磁気ボンド数に応じた動的な伸縮応答を示す (Sudo, et al., 1993).

一方，磁性流体の吸着した小さな永久磁石が外部から交流磁場を受けると，永久磁石に磁気卜ルクが作用し， 磁性流体-永久磁石の素子系にさまざまな運動が誘起される. 著者らは，この磁気卜ルクを利用した幾つかのマイ クロ磁性流体デバイスを提案してきた。たとえば，小さな円柱状永久磁石に磁性流体を吸着させた素子系に交流 磁場を印加することによって，往復運動を行う磁性流体デバイスや回転運動を行うマイクロ磁性流体モータなど の基本原理と駆動特性を報告した（Sudo, et al., 2005, Sudo, et al., 2012a）。また，小さな球状永久磁石に磁性流体を

No.14-00500 [DOI: 10.1299/transjsme.14-00500], J-STAGE Advance Publication date : 28 January, 2015

*1 正員，フェロー，秋田県立大学 システム科学技術学部（†015-0055 秋田県由利本荘市土谷字海老ノ口 84-4）

*2 学生員, 秋田県立大学 システム科学技術学部

*3 正員, 秋田県立大学 大学院 システム科学技術研究科

*4 正員，フェロー，東北大学 流体科学研究所（干980-8577 宮城県仙台市青葉区片平 2-1-1）

E-mail of corresponding author: sudo@akita-pu.ac.jp 
吸着させた素子系に交流磁場を印加し，平板上で振り子振動を行なうスウィング型アクチュエータの駆動特性に ついても報告した（Sudo, et al., 2007）.

本報では, 著者等が先に報告したような磁石一磁性流体素子系に作用する磁気トルクを利用したデバイスではな く, 磁性流体の磁場作用下で示寸動的な界面現象を利用したマイクロ磁性流体デバイスを提案するものである. すなわち，小さなリング円盤状永久磁石に磁性流体を吸着させ，外部交流磁場によって磁性流体の界面運動を誘 起し，非接触駆動方式による滑らかなマイクロ絞り機構を提案し，その系において発生する磁性流体界面現象と 磁性流体デバイスの駆動特性を明らかにしたものである.さらに, 磁石一磁性流体素子系を小さな円管パイプ内に 収めることにより，使用磁性流体量を低減する改良型素子系を試作し，その駆動特性を求めた。

\section{2. 磁性流体の界面現象と絞り機構の原理}

\section{$2 \cdot 1$ 磁石に吸着した磁性流体の界面現象}

磁性流体は磁場の作用下でさまざまな磁気的不安定性を示し，そのような界面現象は，これまで多くの研究者 によって研究報告がなされてきた（Rosensweig, 1985). 著者らも, 小さな円柱形状の永久磁石（直径 $4 \mathrm{~mm}$, 高さ $5 \mathrm{~mm}$ ，表面磁束密度 $430 \mathrm{mT}$ の $\mathrm{NdFeB}$ 磁石）に磁性流体を吸着させ，外部から $5 \mathrm{mT}$ 以下の小さな強さの交流磁 場を印加し，磁性流体の界面応答を調べ，その周波数特性を報告した（Sudo, et al., 2012b）。図 1 は，そのような 磁石一磁性流体素子に交流磁場が作用した場合の磁性流体界面の応答挙動の一例を示している.図 1 における実験 条件は, 磁性流体体積 $V_{m}=8 \times 10^{-7} \mathrm{~m}^{3}(800 \mu \mathrm{l})$, 交流磁場振動数 $f_{0}=60 \mathrm{~Hz}$, ヘルムホルツコイルへの入力電圧全 振幅 $E_{0}=25 \mathrm{~V}$ となっている. 図中の記号 $t$ は時刻を示しており, 時間的に図の左右方向の長さ $l$ が変動している. 図 1 に示した素子系の内部構造を示寸概略図と磁性流体界面の写真を図 2 に示す. 図 2 において, N（赤色）は 永久磁石の $\mathrm{N}$ 極， $\mathrm{S}$ （青色）は $\mathrm{S}$ 極を示している. 図 2 に示すように永久磁石の $\mathrm{N}$ 極と $\mathrm{S}$ 極部分に磁気勾配によ り磁性流体が多く吸着し, 磁石の両磁極方向に平行に外部から交流磁場を印加した素子系の外部磁場による磁性 流体界面応答が図 1 に示されている. 寸なわち, 永久磁石の磁極方向に外部磁場が揃い並行な場合に磁性流体バ ルクは伸長し, 反並行な場合に磁性流体のバルク長 $l$ は縮小寸る. この界面現象は, 一様な磁場作用下におかれ た場合に発生する磁性流体液滴の伸長と基本的に同等である.すなわち, 磁性流体界面における力のバランスは, 圧力を $P$, 磁場の強さを $H$, 真空の透磁率を $\mu_{0}$, 磁性流体液滴の透磁率を $\mu_{d}$, 無磁場下における液滴の半径を $R_{0}$ とすると，式（1）のヤング・ラプラス方程式によって記述される（Afkami, et al., 2010）.

$$
-\llbracket P \rrbracket=-\frac{\mu_{0}}{2}\left(H_{a n}^{2}-H_{a t}^{2}\right)+\frac{\mu_{d}}{2}\left(H_{d n}^{2}-H_{d t}^{2}\right)+\frac{2 \sigma}{R_{0}}
$$

ここで

$$
\begin{aligned}
& H_{d n}=\left(\frac{\mu_{0}}{\mu_{d}}\right) H_{a n}=\frac{3 \mu_{0}}{\mu_{d}+2 \mu_{0}} H_{e} \cos \theta \\
& H_{d t}=H_{a t}=-\frac{3 \mu_{0}}{\mu_{d}+2 \mu_{0}} H_{e} \sin \theta
\end{aligned}
$$

また, $\theta$ は極角, 添字 $a$ は空気, 添字 $d$ は液滴, 添字 $e$ は外部からの印加磁場を示し, 第 2 添字 $n$ と $t$ は各々法線 および接線成分を表わす. 交流磁場作用下の磁性流体バルクは式（1）に従って伸縮応答を示す. 本報で提案する 絞り機構は磁性流体界面のこのような伸縮応答特性を利用したものである. 本報で提案する絞り機構をバルブな どとして液体の流動制御に用いる場合, 数十 $\mathrm{Hz} \sim 100 \mathrm{~Hz}$ 程度の応答性, また気体の流動制御に用いる場合には 数百 $\mathrm{Hz}$ 程度の応答性が求められよう. また, 光シャッター機構などに応用する場合には $\mathrm{DC}$ 数秒〜 $\mathrm{AC}$ 数千 $\mathrm{Hz}$ の広い周波数帯の応答性が求められよう. 本報で提案する絞り機構は振幅の大きさを問わなければ原理的には数 $\mathrm{MHz}$ の応答性を有する.

\section{$2 \cdot 2$ マイクロ絞り機構の原理}

前節で記述したように永久磁石に吸着した磁性流体は, 外部の交流磁場によって伸縮応答を示寸. ここで, 永 久磁石をリング円盤形状として，その磁石に適量の磁性流体を吸着させると，ドーナッツ形状を形成する．永久 


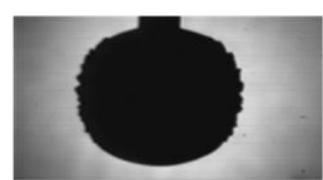

$t=0 \mathrm{~ms}$

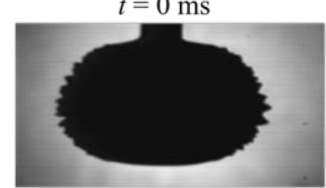

$t=6.2 \mathrm{~ms}$

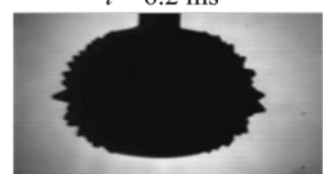

$t=12.4 \mathrm{~ms}$

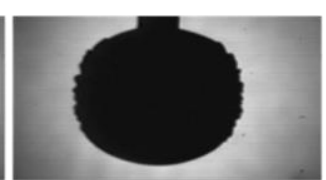

$1.6 \mathrm{~ms}$

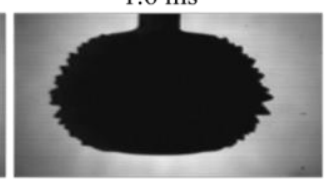

$7.8 \mathrm{~ms}$

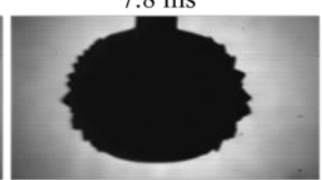

$14.0 \mathrm{~ms}$

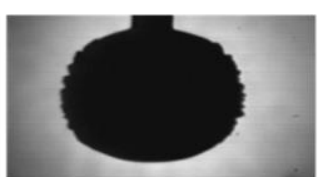

$3.1 \mathrm{~ms}$

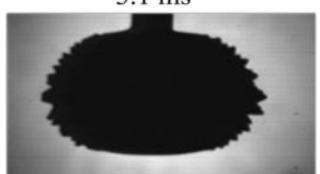

$9.3 \mathrm{~ms}$

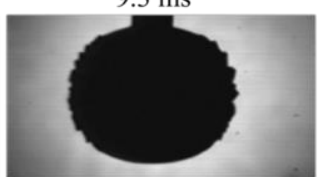

$15.6 \mathrm{~ms}$

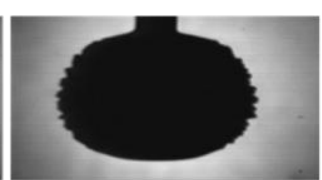

$4.7 \mathrm{~ms}$

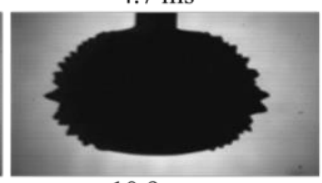

$10.9 \mathrm{~ms}$

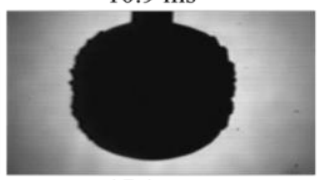

$17.1 \mathrm{~ms}$

Fig. 1 Surface response of magnetic fluid adsorbed on a small permanent magnet subject to alternating magnetic field $\left(V_{m}=8 \times\right.$ $10^{-7} \mathrm{~m}^{3}, f_{0}=60 \mathrm{~Hz}, E_{0}=25 \mathrm{~V}$ ). The surface of magnetic fluid drop responds to alternating magnetic field in the elongation and contraction of its horizontal profile.

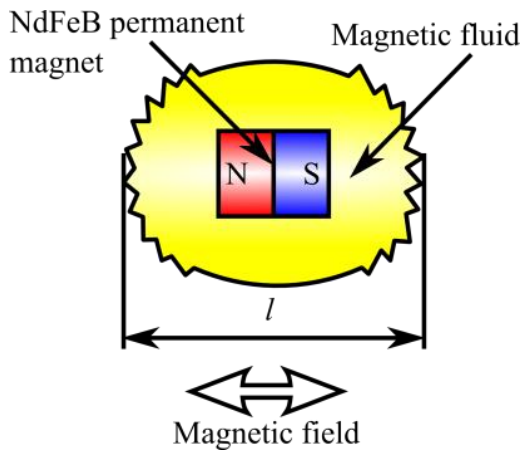

(a)

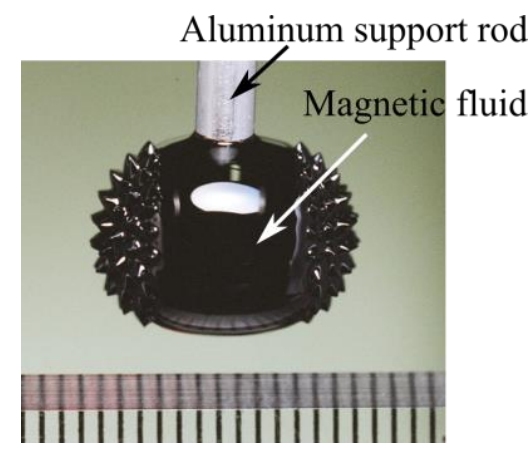

(b)

Fig. 2 Configuration of permanent magnet-magnetic fluid element system; (a) A schematic diagram of magnet-magnetic fluid element is shown. The magnetic fluid held adsorbed in the permanent magnet, (b) Photograph of magnet-magnetic fluid element shows the magnetic fluid surface with the spike pattern produced by the normal-field instability.

磁石は厚み方向に磁極を有するように着磁されてある. 従って, 永久磁石と適量の磁性流体の吸着は, 中心部に ホール (穴)を形成する.この磁石-磁性流体系に外部から永久磁石の磁極と並行な方向に交流磁場を印加寸ると, 磁極方向に沿って磁性流体界面が伸縮応答を示す. 図 3 に磁性流体界面の応答を模式的に示す. 図 3 における(b) の状態が磁石に磁性流体（黄色）が吸着した状態を示している. 図 3 において, 赤色が磁石の $\mathrm{N}$ 極，青色が $\mathrm{S}$ 極 を示している. 磁石に吸着した磁性流体によって形成されたホールは上下の点線の内側部分となる (図 3 中の $D_{h}$ はホール直径を表わしている）。磁石の磁場と並行に外部から磁場が作用した場合, 磁性流体界面は伸長し（図 3 (a)の状態), 反並行の場合に縮小寸る ((c)の状態).この磁石-磁性流体素子の表面形状をトーラスとして近似し， 永久磁石の体積を $V_{p}$, 磁性流体の体積を $V_{m}$ とすると, 全体積 $V$ は

$$
V=V_{p}+V_{m}
$$

であり，トーラスの内径を $R_{1}\left(D_{h}=2 R_{1}\right) ，$ 外径を $R_{2}$ とすれば

$$
V=\frac{1}{4} \pi^{2}\left(R_{1}+R_{2}\right)\left(R_{2}-R_{1}\right)^{2}
$$

で表される. 本報において使用した永久磁石は内径 $6 \mathrm{~mm}$, 外径 $10 \mathrm{~mm}$, 厚さ $1 \mathrm{~mm}$ の円盤リング形状であり, $V_{p}$ は $V_{p}=5.024 \times 10^{-8} \mathrm{~m}^{3}$ となっている. 外部から交流磁場を印加することによって $V_{m}$ にってて形成されるトーラ ス形状を変化させ, 結果的に $R_{1}$ を変化させることになる.特に, 素子系全体を円管パイプにはめ込んだ場合には, 外部交流磁場の変化によって $R_{1}$ のみ変化することになる. 


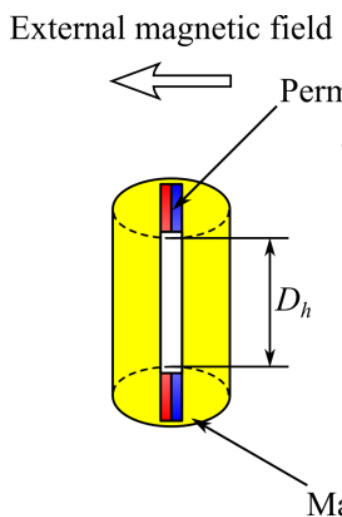

(a)
External magnetic field

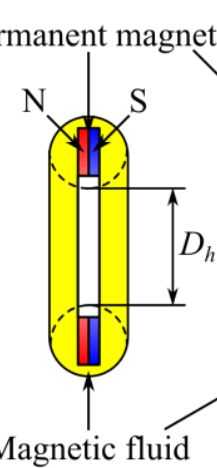

(b)

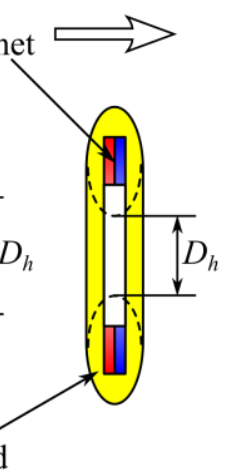

(c)

Fig. 3 Driving principle of micro diaphragm mechanism; (a) Extension state (The external field is parallel to the permanent magnet. The magnetic fluid surface is elongated horizontally by increased magnetic field.), (b) Neutral state (The external field is zero), (c) Reduction state (The external field is anti-parallel to the permanent magnet. The magnetic fluid surface is contracted by the decreased magnetic field.).

\section{3. 実験装置および実験方法}

\section{$3 \cdot 1$ 磁石一磁性流体素子系の基礎的特性}

本報で提案するマイクロ磁性流体絞り機構は，人間の眼の虹彩の機能に倣うデバイスであり，磁気的信号によ って磁性流体ホールの直径を変化する素子である. 人間の眼は光の強弱および波長を受容する感覚器官であり， 角膜と水晶体の間に収縮性の隔壁構造の虹彩がある．虹彩はその中央に開孔する瞳孔を通り，外部から入射する 光の強弱に応じて瞳孔を拡大あるいは縮小する. このような人工絞り機構を前述した原理を用いて磁気的信号に よって磁性流体ホールの拡大・縮小を滑らかに行う絞り機構を実現するものである.

図 4 に実験装置の概略図を示す. 実験装置は試験磁石-磁性流体素子系, 交流磁場生成装置系, 磁性流体ホール 計測装置系から構成されている，磁石一磁性流体素子系は固定するために，永久磁石と ABS 樹脂製の小さな支持 板部分を 2 箇所で接着した. 図 5(a)に磁石一支持板部分の写真, 図 5(b)に磁石に磁性流体を吸着させた写真, 図 5(c) に側方から磁石一磁性流体素子系を眺めた写真を示寸. 図 5(c)の右端は 1 目盛 $1 \mathrm{~mm}$ のスケールである. 使用した 永久磁石は $\mathrm{Nd}_{2} \mathrm{Fe}_{14} \mathrm{~B}$ 磁石であり，外径が $10 \mathrm{~mm}$ ，内径が $6 \mathrm{~mm}$ ，厚さ $1 \mathrm{~mm}$ ，表面磁束密度は $190 \mathrm{mT}$ となってい る. また，試料磁性流体はケロシンベース磁性流体フェリコロイド HC-50である.

交流磁場生成装置系は，周波数シンセサイザー，バイポーラ電源，ヘルムホルツコイルによって構成されてい る. 交流磁場はへルムホルツコイルによって生成した。使用したへルムホルツコイル（Lake Shore MH-6）は磁気 センサ校正用であり，コイル内径は $152.4 \mathrm{~mm}$ である. コイルへの入力信号は周波数シンセサイザー (nf WF 1943) によって生成し，バイポーラ電源（nf HSA4012）によって増幅した. 交流信号は式（6）のような形でコイルに 入力した.

$$
E=\frac{E_{0}}{2} \cos \left(2 \pi f_{0} t\right)
$$

ここで $E_{0} / 2$ は交流電圧の振幅, $f_{0}$ は周波数, $t$ は時間である. 試験素子の周波数特性を求める実験では, 電圧全振 幅 $E_{0}$ を一定として，周波数 $f_{0}$ を変化し，磁性流体ホールの直径振動振幅を求めた.

計測装置系は実験に応じて, 高速度ビデオカメラ装置, 非接触変位計, フォトダイオードセンサシステムを使 い分けた．図 4 の実験装置図には，計測装置系として高速度ビデオカメラ装置（Photron FASTCAM-Ultima-SE） および非接触光学変位計（KEYENCE LK-G3000）を記入してある. 高速度ビデオカメラは主に磁性流体の全体的 な応答挙動を調べるために使用し, 非接触光学変位計およびフォトダイオードセンサシステム $(3 \cdot 3$ 節において 詳述）は，入力信号に対する磁性流体界面などの応答遅れや位相差などが計測できる. 特にフォトダイオードセ ンサシステムは素子系全体を円管パイプ内に収めた改良型素子系において，磁性流体ホールの応答を調べるため に使用した。 


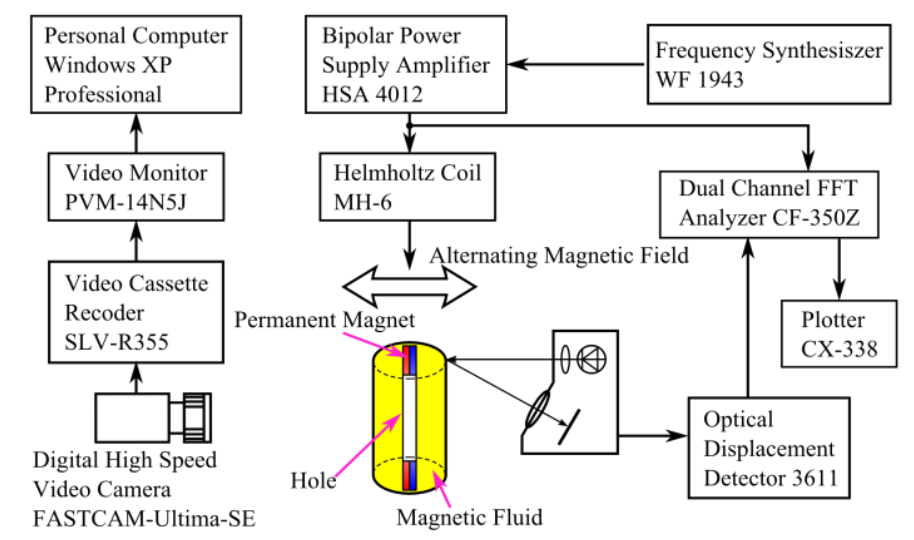

Fig. 4 Schematic diagram of experimental apparatus; The experimental apparatus is composed of the test magnetic fluid diaphragm system, magnetic field generation system, and optical measurement system.

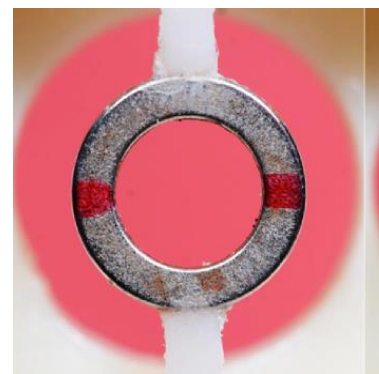

(a)

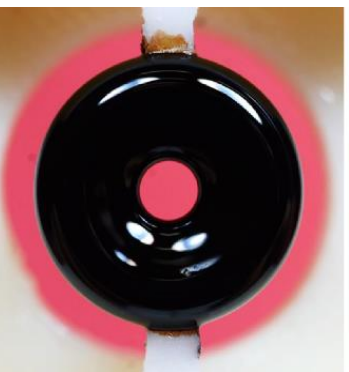

(b)

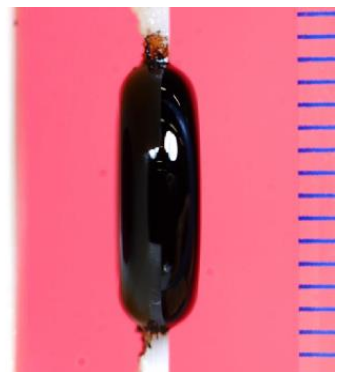

(c)

Fig. 5 Photographs of permanent magnet-magnetic fluid element system; (a) The ring-shaped permanent magnet is supported with two small plates made of ABS resin, (b) Magnetic fluid hole is formed by the magnetic fluid adsorption on the ring shaped magnet, (c) Side view of the permanent magnet-magnetic fluid element.

実験では, 磁石一磁性流体素子系をへルムホルツコイルの中心部に設置し, 永久磁石の磁極方向に沿って外部交 流磁場を印加し，そのときの磁性流体界面応答（磁性流体ホールの直径変化や磁性流体界面振動の変位など）を 調べた．実験は室内常温下で行ない，磁性流体の気温変化による磁気特性の変化は無視できる範囲である.

\section{$3 \cdot 2$ 磁場分布の測定}

本報において使用した永久磁石は，円板の中心部に空孔を有するリング状円盤磁石である．実験に先立ち本報 で使用した永久磁石のまわりの磁場分布を測定した。磁場分布の測定は，マグネット磁気測定装置（ADS 製 MGS-A100）を使用して行った。本装置は，マグネット全般（磁石片または磁気回路）の表面磁場解析を目的と した 3 次元解析システムである. 本システムで使用しているガウスメーターのプローブ（HGM TS-5）は，セン サ数が 3 チャンネル, センササイズが $70 \mu \mathrm{m}$ 角, 温度特性が- $0.06 \% /{ }^{\circ} \mathrm{C}$ となっている. また, 周波数応答は $500 \mathrm{~Hz}$ 以下，測定精度はフルスケールの $\pm 0.5 \%$ 以内である. 入力レンジは $2 \mathrm{mT}, 20 \mathrm{mT}, 200 \mathrm{mT}$ ，および $2 \mathrm{~T}$ のンジ 構成となっている. 測定可能サイズは, 横軸 $X$ 方向 $100 \mathrm{~mm}$, 横軸 $Y$ 方向 $100 \mathrm{~mm}$. 縦軸 $Z$ 軸方向 $100 \mathrm{~mm}$ であり, 位置決め制御分解能は横軸 $0.02 \mathrm{~mm}$, 縦軸 $0.02 \mathrm{~mm}$ となっている. 解析結果は 3 次元解析ソフトを使用してグラ フ表示, ベクトル表示, 等高線表示が可能である. 測定においては, 室温 $18{ }^{\circ} \mathrm{C} \sim 28^{\circ} \mathrm{C}$ で高精度測定が推奨され ており，この温度範囲で測定を行った。

\section{$3 \cdot 3$ 円管内素子の駆動特性実験}

マイクロ絞り機構の基本的な原理については $2 \cdot 2$ 節に記述した通りであるが，磁性流体のむだを小さくし，よ り少ない量で駆動するために素子全体をコンパクトに収めた改良型を試作し，その駆動特性についても調べた. 試作した改良型の磁石一磁性流体素子の概略寸法図(a)およびその素子において形成された磁性流体ホールの写真 


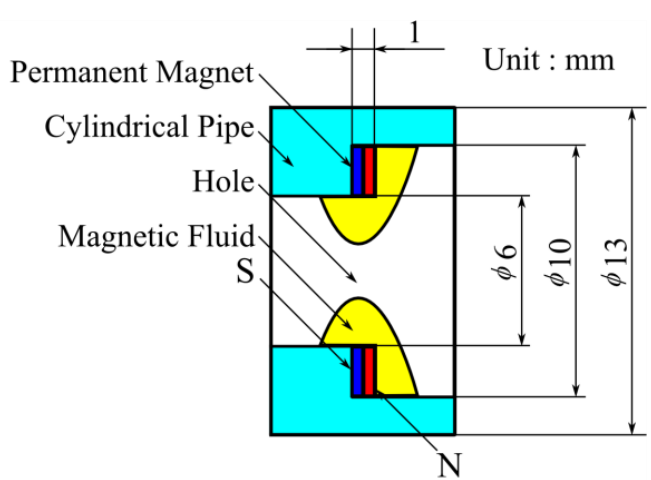

(a)

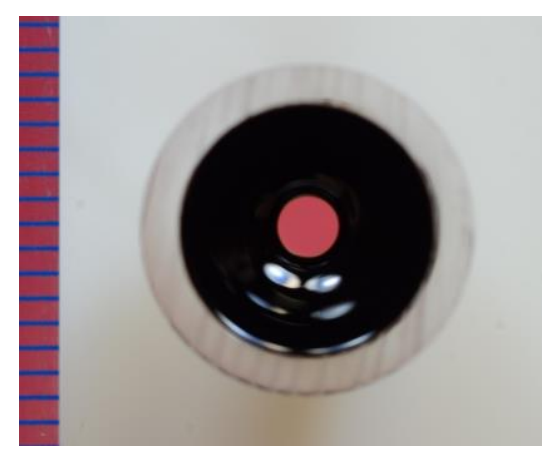

(b)

Fig. 6 Improved model of magnet-magnetic fluid element system; (a) Schematic and dimensions of the element, (b) Photograph of magnetic fluid hole $\left(V_{m}=1 \times 10^{-7} \mathrm{~m}^{3}\right)$. The magnetic fluid diaphragm is packed into the circular acrylic pipe.

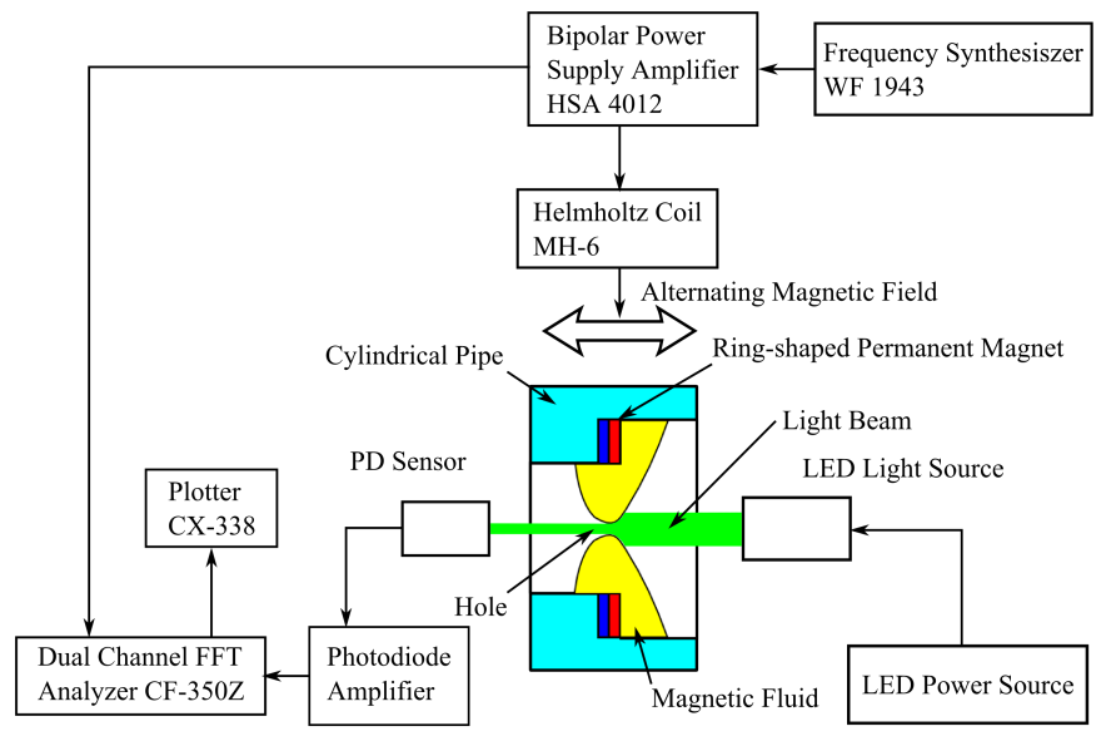

Fig. 7 Schematic diagram of experimental apparatus for observation of magnetic fluid hole; The photodiode sensor system is used to measure the hole diameter of magnetic fluid.

(b)を図 6 に示す.図6(a)において $\mathrm{S}$ は永久磁石の $\mathrm{S}$ 極, $\mathrm{N}$ は $\mathrm{N}$ 極を示している,また, 図 6(b)の右端は 1 目盛 $1 \mathrm{~mm}$ を示すスケールである，磁石一磁性流体を覆う円管は，アクリル樹脂製であり，磁性流体のむだを省くために内部 に段差を設けた。この素子の駆動特性を調べる実験装置は前述した図 4 とほぼ同じであるが，精度よく磁性流体 ホールの応答挙動を調べるために，計測装置としてフォトダイオードセンサシステムを使用した. フォトダイオ ードセンサシステムには, 緑色（波長 $550 \mathrm{~nm}$ ）の発光ダイオードとハイパワーLED ランプ用コリメートレンズを 組夕合わせて光源とし, 受光部には GaAsP フォトダイオード (受光面サイズ $2.7 \mathrm{~mm} \times 2.7 \mathrm{~mm}$, 感度波長範囲 300 ～ $680 \mathrm{~nm}$ ）を用いた。 フォトダイオードセンサシステムを配置した実験装置の概略図を図 7 に示す. 本システム は，特にヘルムホルツコイルへの入力電圧と磁性流体ホールの忘答出力の関係を調べるために使用した.

\section{4. 実験結果および考察}

\section{$4 \cdot 1$ 永久磁石まわりの磁場分布}

本報において使用した $\mathrm{NdFeB}$ 磁石のまわりの磁場分布を，3・2 節において前述した装置を用いて計測した. 実験で使用した磁石は表面磁束密度 $190 \mathrm{mT}$ として公表されている市販品であるが，実験に先立ち磁場分布を計 


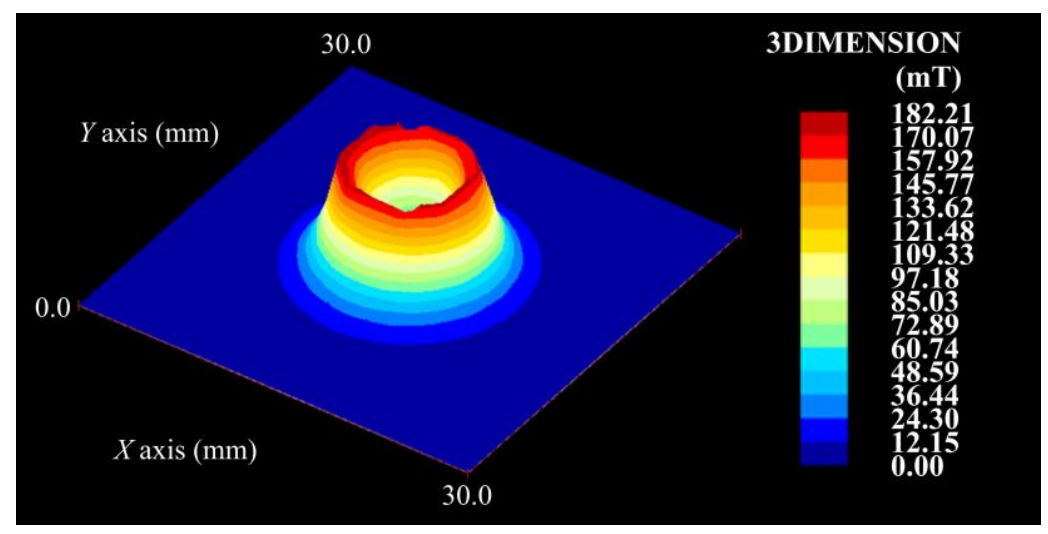

(a)

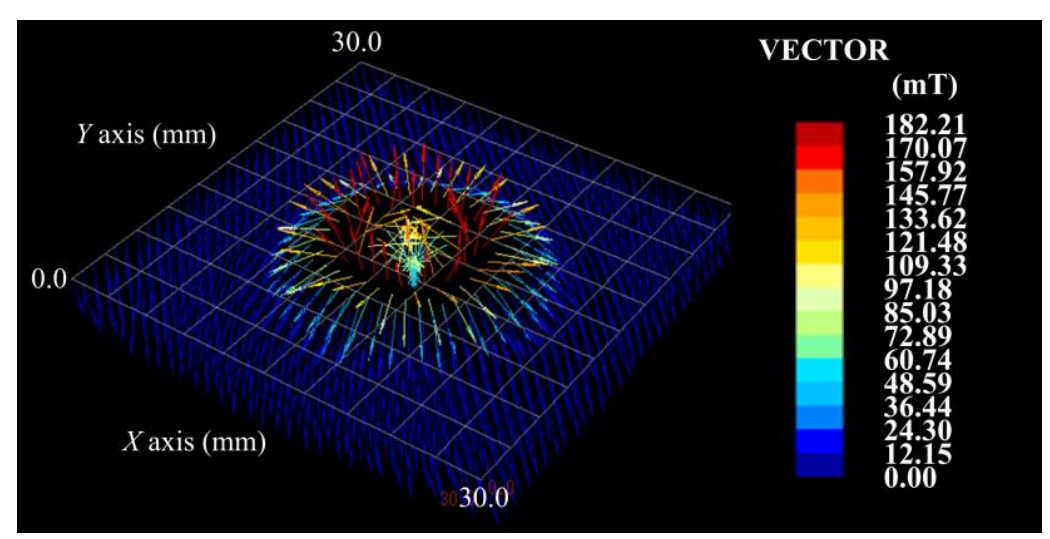

(b)

Fig. 8 Distribution of magnetic field around the permanent magnet; (a) 3D description of magnetic flux density with the color scale code, (b) Vector diagram of magnetic field described by the arrows (direction) and color scale (magnetic flux density).

測した. 図 8 に計測結果の一例を示す. 本報で使用した磁石は外径 $10 \mathrm{~mm}$, 内径 $6 \mathrm{~mm}$, 厚さ $1 \mathrm{~mm}$ のリング円盤 形状（図 5(a)参照）であり，磁石を水平（ $X-Y$ 軸平面）に置き，磁石表面から $0.2 \mathrm{~mm}$ 上方に離れた位置（ $Z$ 軸） で， $X-Y$ 軸平面をプローブでスキャンし，磁場分布を測定した．図 8(a)が磁束密度の 3 次元表示， (b)がベクトル 線図を示している. 図 8 におけるカラーコードは磁束密度に対応し, 図 8 中に色目盛が示されている.すなわち, 色目盛は磁束密度 0 182.21 mT までを濃い青色から濃い赤色で 15 段階に分割して表示してある. 磁石のリング 部分に沿って磁束密度が高く，中心部分で大きく窪んでいることがわかる．また，ベクトル線図 8(b)からリング 外輪部分で磁場の方向が水平あるいは下方に向き，リング中央部分で上方に向いている.また，リング内輪部分 は水平から下方に向いている. 磁場の強さは, 磁石表面で高く, 磁石から離れるにしたがい弱くなる. そのため, リング形状磁石に磁性流体を近づけると, 磁気体積力によって磁性流体が吸着され, 図 5(b)に示した磁性流体ホ 一ルが形成される。この磁石-磁性流体の素子系に外部から交流磁場を印加すると, その磁場に対応した磁性流体 の界面変位応答が生じる.

\section{4-2 磁性流体界面の交流磁場に対する伸縮応答}

永久磁石に吸着した磁性流体が，磁石の磁極方向に外部から交流磁場を受けると，図 1 に示したように磁性流 体界面は伸縮応答を示す．この現象はリング状磁石の場合でも全く同様に発生する．本報で使用したリング円盤 状の磁石は厚み方向に磁極が構成されている．本磁石に磁性流体が吸着した磁石一磁性流体素子系（図 5(c)）に外 部から磁極方向に交流磁場を作用させた場合の磁性流体の界面応答を調べた.

図 9 は結果の 1 例を示す高速度ビデオカメラ撮影フレームから磁性流体の界面振動のおよそ 1 周期分を並べた 写真である. 実験条件は, 磁性流体体積 $V_{m}=3 \times 10^{-7} \mathrm{~m}^{3}$, 周波数 $f_{0}=140 \mathrm{~Hz}$, 印加電圧全振幅 $E_{0}=60 \mathrm{~V}$ である. 磁性流体の厚さ (横幅) が変化した応答を示しているが, 変位が小さく分かりにくい. そのため, 非接触光学変 

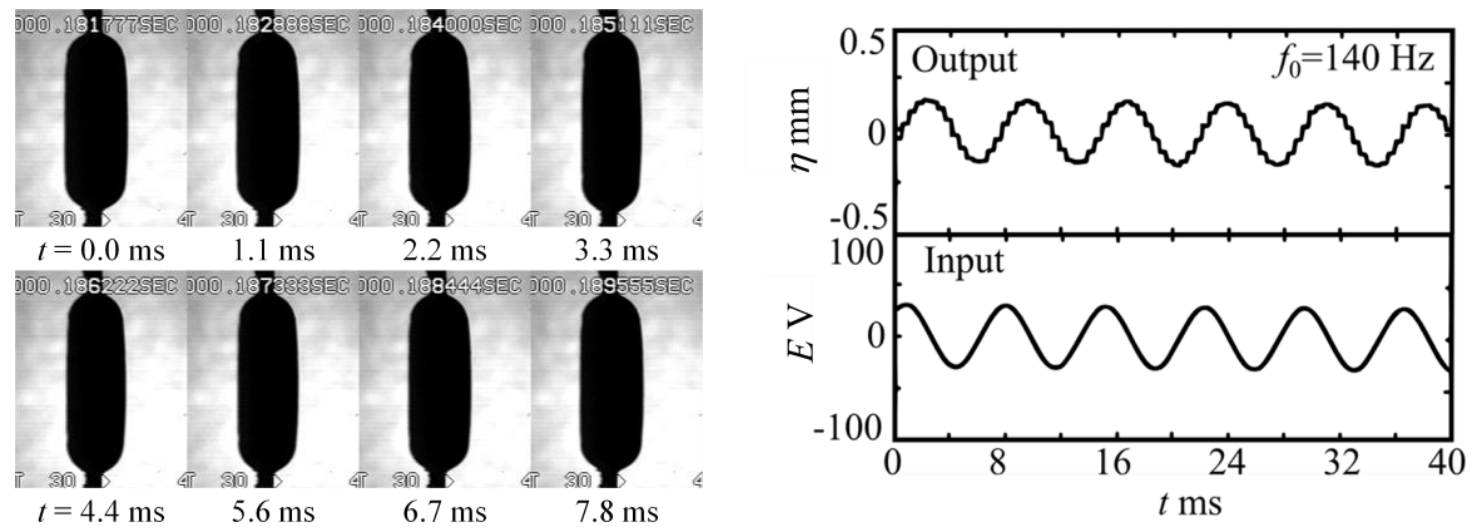

Fig. 9 Photographs of the vibration sequence for magnetic fluid subject to alternating magnetic field show the response of fat and thinning.

Fig. 10 Input voltage signal and surface oscillation of magnetic fluid $\left(V_{m}=3 \times 10^{-7} \mathrm{~m}^{3}, f_{0}=140 \mathrm{~Hz}, E_{0}=60 \mathrm{~V}\right)$. Upper signal shows the surface vibration, and lower shows the input signal.

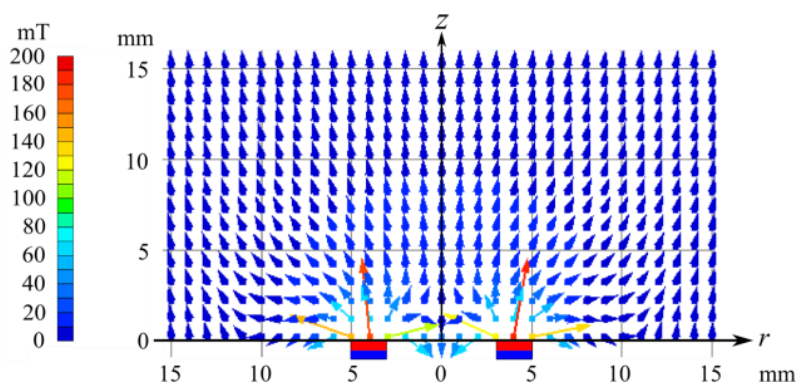

(a)

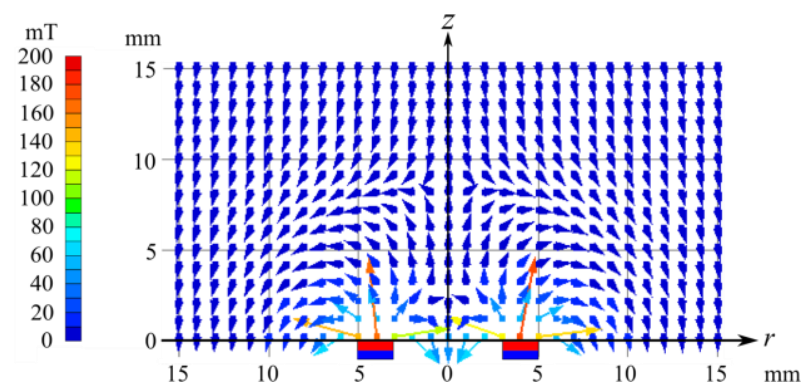

(b)

Fig. 11 Magnetic field around the permanent magnet subject to alternating magnetic field; (a) The permanent magnet and coil magnetic field are parallel, (b) The permanent magnet and coil magnetic field are anti-parallel. These two figures show the magnetic field fluctuations that the magnetic fluid is subjected.

位計によって，図 9 における水平方向の磁性流体界面振動を計測した結果を図 10 に示す．図 10 の下段の波形は ヘルムホルツコイルへの入力電圧信号を示し，上段の波形は非接触光学変位計からの出力波形を示している. 上 段の波形が階段状の信号となっているのは，変位データ採取のサンプリング時間のためである. 図 10 の下段（入 力）上上段（出力）の比較から, 磁性流体の界面応答には入力に対しておよそ $1.5 \mathrm{~ms}$ 程度の遅れ（位相差）のあ ることがわかる. 図 10 における実験条件は, 図 9 の場合と全く同様である.このように, 磁性流体界面は外部磁 場に対して，図9に示したように水平幅方向に伸縮する調和振動を示寸.

このような磁性流体界面の伸縮振動は磁性流体周りの磁場が時間的に変化することによってもたらされる. 本 実験で使用した永久磁石およびヘルムホルツコイルによって形成される磁場分布を調べた。 その結果（へルムホ ルツコイルへの入力電圧が $E_{0}=60 \mathrm{~V}$, 周波数 $f_{0}=20 \mathrm{~Hz}$ における最大值および最小值の場合）を図 11 に示寸. 図 11(a)は永久磁石の磁極方向とへルムホルツコイルの生成する磁場が並行でコイル生成磁場が最大值に達した場 合のベクトル線図を示し, 図 11(b)は永久磁石の磁場とコイルの生成する磁場が反並行で, コイル生成磁場が最大 值に達した場合のベクトル線図を示している.これらの磁場ベクトル分布はいずれも磁性流体が永久磁石に吸着 していない場合の状態を示している. 図 11 において, 永久磁石表面を原点として上方に $z$ 軸を設定し, リング中 心を原点として半径方向に $r$ 軸を設定した. また, 赤色と青色で構成される四角形は磁石の断面で, 赤色は $\mathrm{N}$ 極, 青色は S 極を表している. 永久磁石の磁場方向とコイル生成磁場の方向が同じ方向に揃った場合は, 磁場の強さ が強調され (図 11(a)), 両者の磁場が反並行の場合, 永久磁石の生成する磁場の方向が図 11 における $z=10 \mathrm{~mm}$ 程度を境にして, 磁場方向が異なり, 永久磁石周辺の磁場方向に曲がりが見られる (図 11(b))。このような永久 磁石周辺の磁場分布の相違が磁性流体界面の変形を誘起し, 磁性流体界面の伸縮振動を生成する. 


\section{$4 \cdot 3$ 磁性流体ホールの応答}

前節で示したように，リング円盤形状の永久磁石に吸着した磁性流体に外部から交流磁場を印加すると，磁性 流体界面は伸縮振動を示す，それに伴ない，図３に示したように磁性流体ホールはその直径を拡大・縮小する忘 答を呈する.図 5 に示した磁石一磁性流体素子が外部から交流磁場を受けた場合の磁性流体ホールの応答の例を図 12 に写真で示す.図 12(a)は高速度ビデオカメラ撮影フレームからおよそ 1 周期分を取り出し並べた写真であり, 実験条件は $V_{m}=3 \times 10^{-7} \mathrm{~m}^{3}(300 \mu \mathrm{l}), f_{0}=140 \mathrm{~Hz}, E_{0}=60 \mathrm{~V}$ となっている. 図 12(a)から磁性流体ホールの直径は 拡大と縮小をくり返していることがわかる。この磁性流体ホール直径の時間変化を画像解析から求めた結果を図 12(b)に示す. 図 12(b)における横軸は時刻 $t$, 縦軸は磁性流体ホール直径 $D_{h}$ である. 図 12(b)から， $D_{h}$ は外部交流 磁場と同じ周波数で拡大・縮小をくり返していることがわかる.

このような磁性流体ホール直径の応答を交流磁場の周波数 $f_{0}$ を変えて調べた。図 13 に $f_{0}=76 \mathrm{~Hz}$ 場合の磁性流 体ホールの応答を示す.図 13 からホール直径振動はやはり交流磁場の周波数と同様であり調和振動であることが わかる、しかしながら，振動の振幅は図 12 と比較して小さくなっており， $E_{0}$ を一定とした条件において周波数 依存性のあることが明らかである. 実験において観察された磁性流体ホール直径の振動は近似的に式（7）によっ て記述される。

$$
D_{h}=D_{i}+D_{a} \cos \left(2 \pi f_{0} t-\phi\right)
$$

ここで， $D_{i}$ は磁性流体ホールの初期直径， $D_{a}$ はホール直径の振動振幅， $\phi$ は式（6）の入力電圧 $E$ との位相差であ

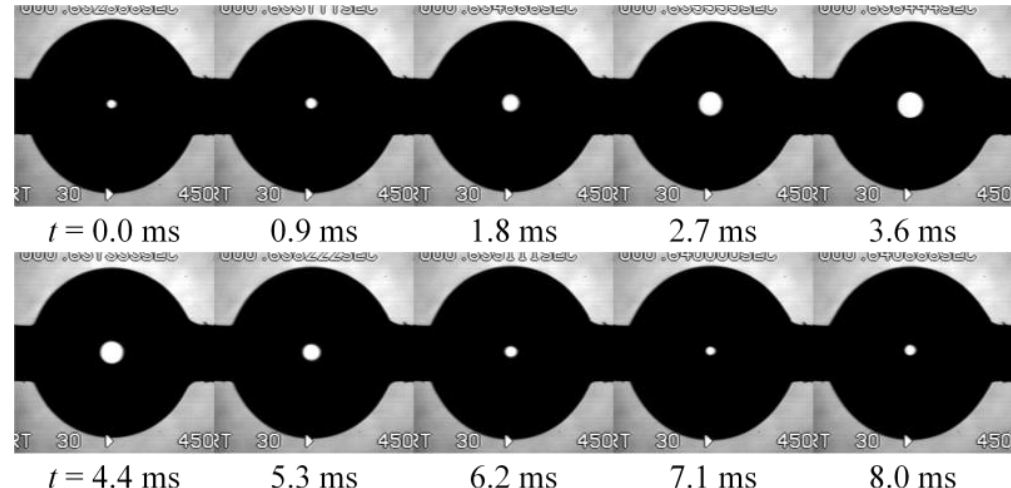

(a)

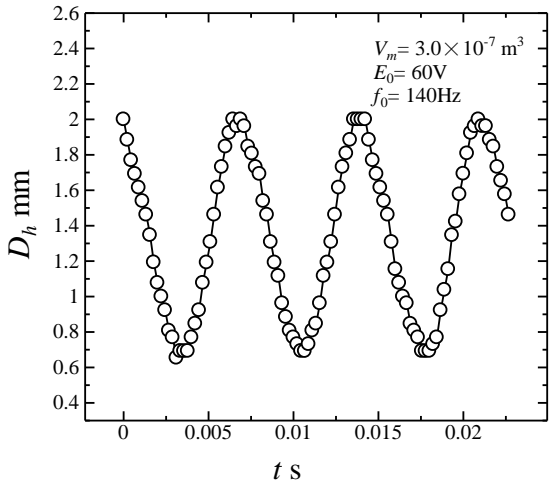

(b)

Fig. 12 Response of magnetic fluid hole in alternating magnetic field $\left(V_{m}=3 \times 10^{-7} \mathrm{~m}^{3}, f_{0}=140 \mathrm{~Hz}, E_{0}=60 \mathrm{~V}\right)$; (a) Photographs of magnetic fluid hole response show the process of expansion and contraction in magnetic fluid hole, (b) Time variation of magnetic fluid hole diameter shows the periodic surface vibration.

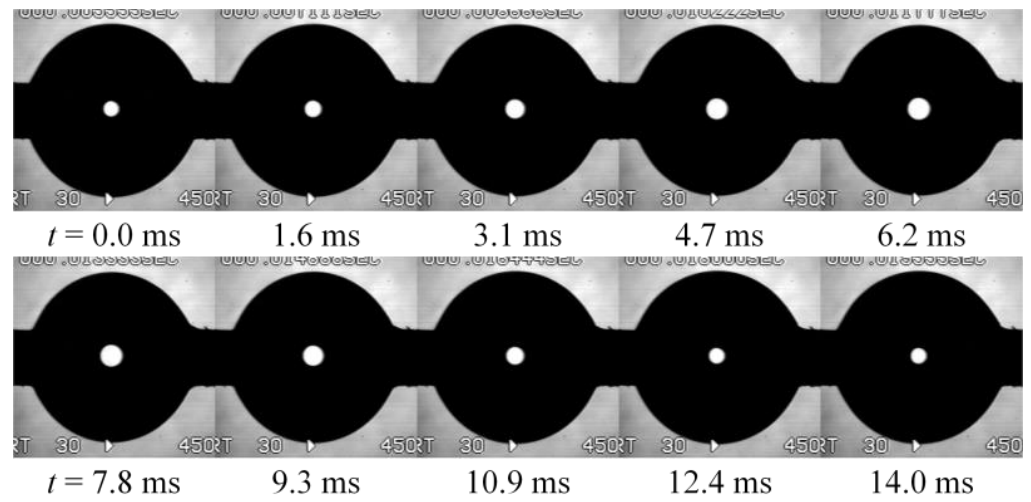

(a)

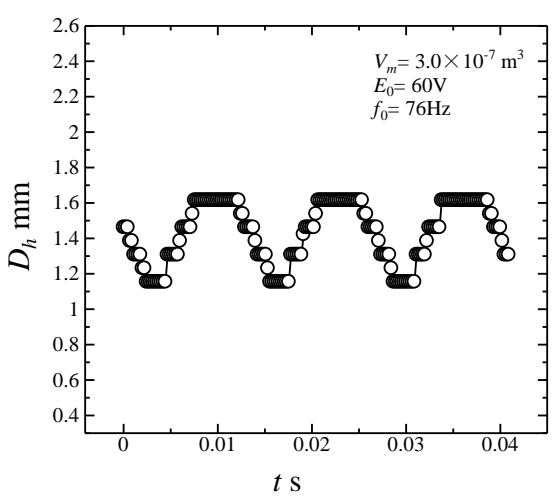

(b)

Fig. 13 Response of magnetic fluid hole in alternating magnetic field $\left(V_{m}=3 \times 10^{-7} \mathrm{~m}^{3}, f_{0}=76 \mathrm{~Hz}, E_{0}=60 \mathrm{~V}\right)$; (a) Photographs of magnetic fluid hole response show the process of expansion and contraction in magnetic fluid hole, (b) Time variation of magnetic fluid hole diameter shows the periodic surface vibration. 
る. 図 12 と図 13 の比較から，本実験において $D_{a}$ は $f_{0}$ の関数であることがわかる. すなわち， $E_{0}=60 \mathrm{~V}$ の条件 で $D_{h}$ の振動振幅 $D_{a}$ は $f_{0}=140 \mathrm{~Hz}$ において大きく, $f_{0}=76 \mathrm{~Hz}$ において小さい.

\section{$4 \cdot 4$ 磁性流体ホール振動の周波数特性}

前節で示したように, $E_{0}$ を一定として $f_{0}$ を変えて実験を行った場合, 磁性流体ホールの直径の振動振幅は周波 数 $f_{0}$ によって異なる. そのため, 磁性流体ホール振動の周波数依存性を調べた. その結果を図 14 に示寸. 図 14 における縦軸 $D$ は式（8）によって定義される磁性流体ホール振動の無次元全振幅である.

$$
\bar{D}=\frac{D_{h \max }-D_{h \min }}{D_{i}}
$$

ここで, $D_{h \max }$ は磁性流体ホール直径の最大值， $D_{h \min }$ は最小值である. 図 14 には，ヘルムホルツコイルヘの印加 電圧の全振幅が $E_{0}=60 \mathrm{~V}$ および $E_{0}=30 \mathrm{~V}$ の場合の周波数特性を示している. 図 14 から, $\bar{D}$ が特定の周波数で ピークを示していることがわかる. しかもピークを示寸周波数は $E_{0}$ が異なっても同じであることも明らかである. 寸なわち, この周波数は磁石一磁性流体素子系における磁性流体界面振動の固有振動数と考えられ, 外部交流磁場 の周波数と磁性流体界面振動が共振状態にあると考えられる.

図 14 からも明らかなように， $E_{0}$ の值によって $D$ の值の異なることがわかる. 磁性流体界面振動におよぼす $E_{0}$ の効果を調べた. 実験では周波数 $f_{0}$ を一定として, $D$ におよぼす $E_{0}$ の効果を調べた. 結果の 1 例を図 15 に示す.

図 15 は， $f_{0}$ を一定として， $E_{0}$ を変化させ $\bar{D}$ の值を調べたもので, $E_{0}$ の増大に伴って $\bar{D}$ の值が増加していること を示している.この結果は, 比較的周波数が低い場合には, $E_{0}$ の増加がそのままコイルの電流の増加につながり, その電流に比例して磁場の強さが増大寸るためである.また, 図 14 において周波数が比較的高い場合 $\left(f_{0}>200 \mathrm{~Hz}\right)$, $\bar{D}$ の值は小さくなる. これは, $E_{0}$ を一定とし $f_{0}$ を変化させた場合, コイルを流れる電流が周波数が低い場合と比 べ電流の值が小さくなるためである。すなわち，コイルを流れる電流 $I$ は式（9）で記述され， $I$ は $f_{0}$ と逆比例の 関係にあるためである.

$$
I=E_{0} /\left(4 \pi j f_{0} L\right)
$$

ここで, $j=\sqrt{-1}, L$ はコイルのインダクタンスである.

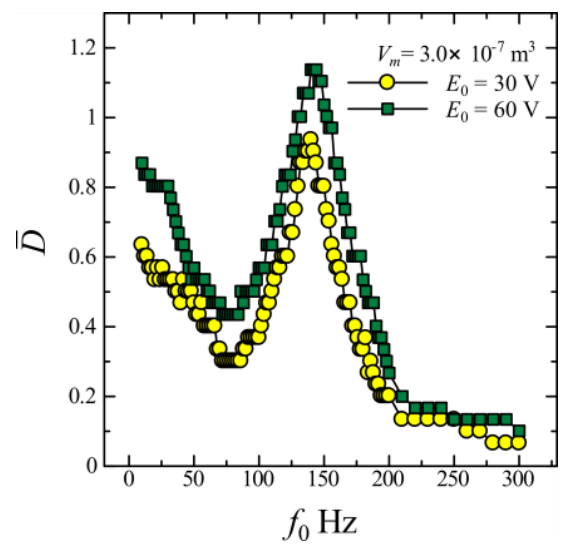

Fig. 14 Frequency characteristics of magnetic fluid hole oscillation $\left(V_{m}=3.0 \times 10^{-7} \mathrm{~m}^{3}\right)$. The peak frequency is $f_{0}=140 \mathrm{~Hz}$.

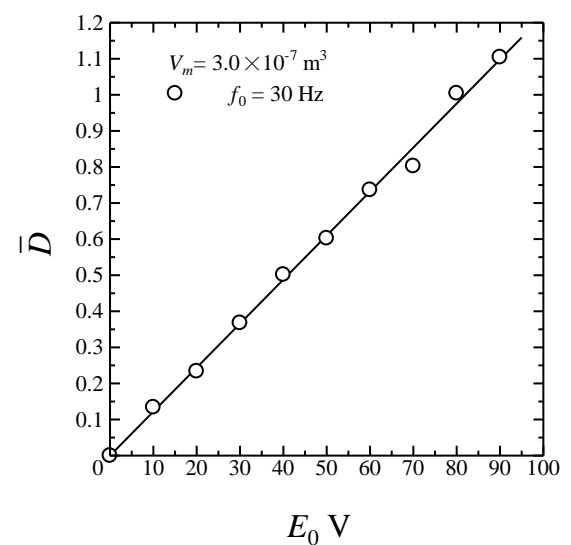

Fig. 15 Effect of applied voltage on the total dimensionless amplitude of magnetic fluid hole oscillation $\left(f_{0}=30\right.$ $\mathrm{Hz}$ ). The dimensionless amplitude $\bar{D}$ is proportional to $E_{0}$.

\section{5. 改良型磁石一磁性流体素子の特性}

前章において示したように，リング円盤形状の永久磁石に吸着された磁性流体に永久磁石の磁極方向に交流磁 場を印加すると, 磁性流体界面が交流磁場に対応した振動を生成し, 磁性流体ホール直径は拡大・縮小をくり返 す.この磁性流体ホール振動を絞り機構として利用する場合, リング円盤状永久磁石に吸着した外輪部分の磁性 
流体は不必要である.さらに, 絞り機構として本磁石-磁性流体素子を利用する場合, 磁性流体が剥き出しとなる 不都合もある，そのため，素子系を円管パイプ内に収めた改良型を試作した（図6参照)。ここでは，改良型の磁 石一磁性流体素子の駆動特性を調べた.

\section{$5 \cdot 1$ 磁性流体ホールの交流磁場応答}

磁石一磁性流体素子を円管パイプ内に収めた場合でも, 磁性流体ホールは交流磁場を受けると拡大・縮小の振動 応答を示した．そのような応答挙動の一例を図 16 に写真で示す. 図 16 における実験条件は, $V_{m}=1 \times 10^{-7} \mathrm{~m}^{3}, f_{0}$ $=80 \mathrm{~Hz}, E_{0}=60 \mathrm{~V}$ である. 図 12 や図 13 で写真に示した磁性流体の場合, 磁性流体ホールだけではなく, 磁性流 体の外径にもわずかに拡大・縮小の界面振動が現れる. しかし, 円管パイプ内に素子が収められた場合, 円管壁 で磁性流体の流動が制限されるため, より少ない磁性流体量で有効なホール振動が得られている. すなわち, 改 良型では前述の素子で用いた磁性流体量の 3 分の 1 となっている. 改良型素子は周辺がパイプによって閉じられ ているため, 磁性流体ホールの直径振動を $3 \cdot 3$ 節において記述したフォトダイオードセンサシステムによって微 小な振幅振動まで計測できる. フォトダイオードセンサシステムを使用した計測例を図 17 に示寸. 図 17 は $f_{0}=20$ $\mathrm{Hz}, f_{0}=115 \mathrm{~Hz}, f_{0}=1000 \mathrm{~Hz}$ の場合の, ヘルムホルツコイルへの入力電圧信号 $E$ およびフォトダイオードセンサ システムからの出力電圧信号 $E_{P}$ を同時刻で示している. 図 17 から外部交流磁場の周波数が $f_{0}=1000 \mathrm{~Hz}$ において もホールは，交流磁場に対応寸る応答を示していることがわかる．また，図 17 における出力電圧 $E_{P}$ の縦軸スケ 一ルの相違からホール振動の振幅が $f_{0}$ の増加に伴って減少することも明らかである.

\section{$5 \cdot 2$ 磁性流体界面振動の応答遅れ}

本磁石一磁性流体素子において, 外部交流磁場の印加は磁性流体がおかれている空間の磁場を変えて磁性流体の 流動を誘起し, 磁性流体ホールの振動を生成する原理となっている. 従って, 永久磁石に吸着した磁性流体は, 外部交流磁場に従って，永久磁石に向から内向き流れと永久磁石から遠ざかる外向き流れの振動流を呈する。一 般に，ヘルムホルツコイルに電圧を印加し，外部磁場を生成してから磁性流体が流動を始めるまでには，遅れが

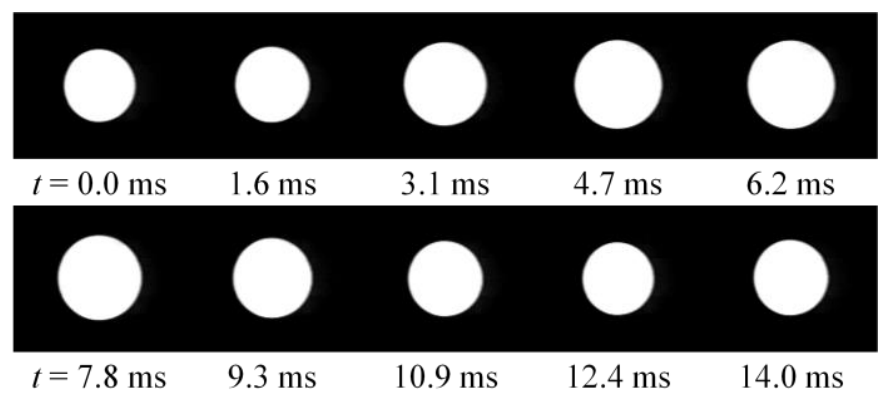

Fig. 16 Response of magnetic fluid hole in the pipe subject to alternating magnetic field $\left(V_{m}=1 \times 10^{-7} \mathrm{~m}^{3}, f_{0}=80 \mathrm{~Hz}, E_{0}=60 \mathrm{~V}\right)$. The magnetic fluid hole repeats expansion and reduction in its diameter.

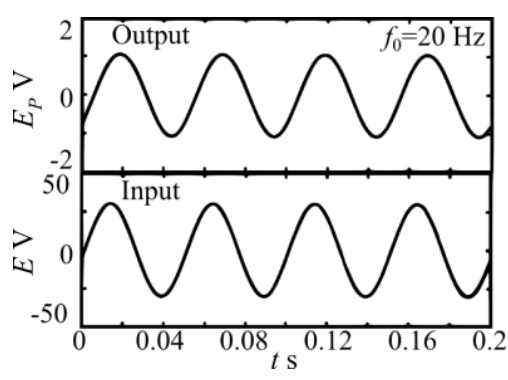

(a)

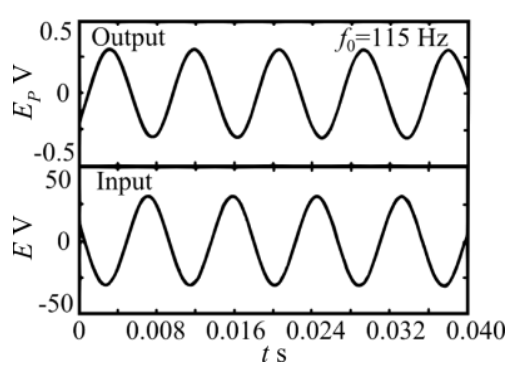

(b)

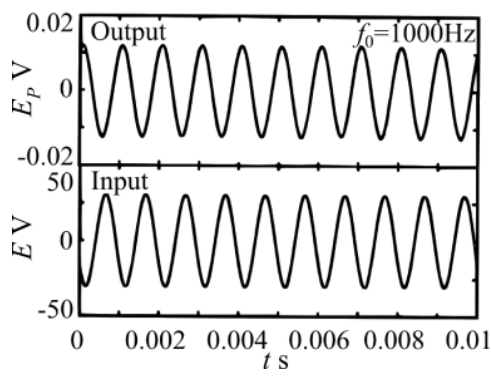

(c)

Fig. 17 Relationship between input and output voltage signals; (a) $f_{0}=20 \mathrm{~Hz}$, (b) $f_{0}=115 \mathrm{~Hz}$, (c) $f_{0}=1000 \mathrm{~Hz}$. The magnetic fluid hole presents harmonic response at any frequencies. 
生じる. フォトダイオードセンサシステムを使用して電圧印加から磁性流体の応答までの時間を $f_{0}=20 \mathrm{~Hz}$ の場 合に関して調べた. 図 18 はヘルムホルツコイルへの入力電圧 $E$ (図 17 下段の信号) とフォトダイオードセンサ システムからの出力電圧 $E_{P}$ (図 1 上段の信号) の関係を示している. 図 17 の上段の信号は磁性流体ホールの変 動に対応しており，下段の入力電圧信号に対して時間遅れのあることが明らかである. 図 18 における時間遅れは およそ $2.4 \mathrm{~ms}$ 程度となっている. 交流磁場の周波数が高い場合には, 入力に対する磁性流体応答の遅れが大きな

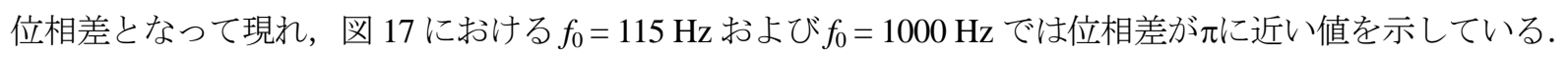

\section{$5 \cdot 3$ 磁性流体ホールの完全閉塞}

前述したように, 磁性流体ホールは交流磁場の作用下で, ホール直径の拡大・縮小振動を示寸. 本磁石一磁性流体 素子において磁性流体ホールが完全に閉じるようにするためには, ホール直径振動の振幅を増大寸る必要がある. すなわち，外部交流磁場の振幅を大きくする必要がある.しかし，本実験においてへルムホルツコイルに印加し た電圧振幅程度でも, 磁性流体の吸着量を変えることによって磁性流体ホールを完全に閉じる状態を実現できる. 周波数 $f_{0}=20 \mathrm{~Hz}$ の場合に関して, 完全に閉じた状態からホールが生成され，再び閉じるまでの応答を写真で図 19 に示寸. 図 19 において, $t=0$ で完全に閉じた状態から $t=1.3 \mathrm{~ms}$ ではホールがすでに形成され，急速に $D_{h}$ を 増大させ, $t=4.0 \mathrm{~ms}$ では最大直径に達している. その後, $D_{h}$ は次第に減少し, $t=14.7 \mathrm{~ms}$ で再びホールは完全に 閉じている，交流磁場の一周期において，磁性流体ホールが形成されている時刻を除く他の時刻においては，ホ 一ルは完全に閉じている．ここで，永久磁石に吸着している磁性流体の体積は $V_{m}=1.1 \times 10^{-7} \mathrm{~m}^{3}$ となっている. すなわち，磁性流体の吸着量を調整することによって完全に閉じるホール応答を実現できる，ただし，使用する 永久磁石の寸法をそのまま一定として, 磁性流体の吸着量を変えることは式（7）の $D_{i}$ を変えることになる. そのため, 目的に合わせた絞り機構と寸るには，永久磁石の寸法および磁性流体の吸着量を目的に合わせて選定 する必要がある。ここで提案する絞り機構は微小化が容易で, 交流磁場の生成の観点からもマイクロシステムに おいて有利であると考えられる.

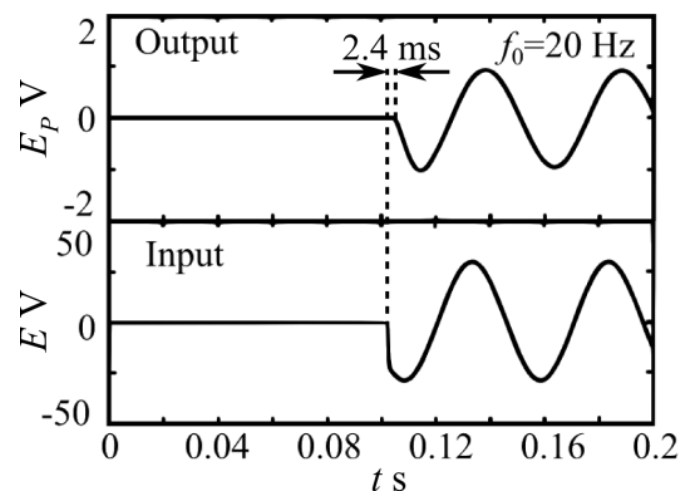

Fig. 18 Response delay of magnetic fluid in the output to input voltage signal is $2.4 \mathrm{~ms}$ at $f_{0}=20 \mathrm{~Hz}$.

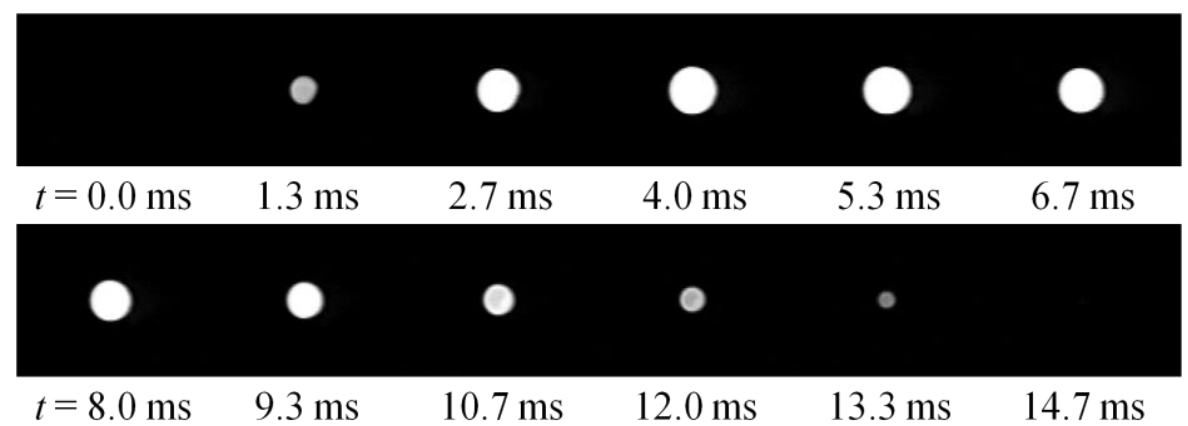

Fig. 19 Photographs showing hole response with the complete shut $\left(V_{m}=1.1 \times 10^{-7} \mathrm{~m}^{3}, f_{0}=20 \mathrm{~Hz}, E_{0}=60 \mathrm{~V}\right)$. The magnetic fluid hole presents harmonic response and complete closing. 


\section{6. 結 言}

小さなリング円盤状永久磁石に磁性流体を吸着させた磁石一磁性流体素子に外部から交流磁場を印加し, 磁気的 信号によって応答するマイクロ磁性流体絞り機構を構築し, 磁性流体の界面応答および駆動特性を調べた. さら に, 実用性を考慮した改良型磁石一磁性流体素子を試作し，その諸特性を調べた. 得られた結果をまとめると以下 のようになる.

（1）小さなリング円盤状永久磁石に磁性流体を吸着させ，磁性流体ホールを形成した系が交流磁場を受けると， 磁性流体の自由界面に伸縮振動が誘起され，それに伴って磁性流体ホールが拡大縮小の応答を呈する.

（2）磁性流体ホールの交流磁場に対寸る応答の周波数特性は, ヘルムホルツコイルへの入力電圧振幅を一定とし た条件において特定の入力周波数で応答無次元全振幅がピークを示す.

（3）磁性流体ホール直径の振動振幅は, 交流磁場の周波数を一定とした場合, ヘルムホルツコイルヘの入力電圧 の増加とともに増大する。

（4）磁石一磁性流体素子系を円管パイプ内に収めた場合，より少ない吸着磁性流体量で磁性流体ホールの振動を 呈するシステムを構築できる。

（5）永久磁石に吸着される磁性流体の量を調整することによって, 磁性流体ホールが外部交流磁場の作用によっ て完全に閉じるシステムを構築できる.

（6）磁性流体ホールは，1000 Hz 程度の比較的高い周波数の交流磁場に対しても振動応答を呈する.

\section{謝 辞}

本研究の一部は東北大学流体科学研究所の公募共同研究（J14007）の助成を受けて行われたものである.ここ に記し，謝意を表寸る．また，円管内素子の駆動特性実験において使用したフォトダイオードシステムの製作で は東北大学流体科学研究所技術補佐員 片桐一成氏の助力を得た。ここに記し, 謝意を表する.

\section{References}

Afkhami, S., Tyler, A. J., Renardy, Y., Renardy, M.Pierre, T. G. St., Woodward, R. C. and Riffle, J. S., Deformation of a hydrophobic ferrofluid droplet suspended in a viscous medium under uniform magnetic fields, Journal of Fluid Mechanics, Vol.663 (2010), pp.358-384.

Cowley, M. D. and Rosensweig, R. E., The interfacial stability a ferromagnetic fluid, Journal of Fluid Mechanics, Vol.30, part4 (1967), pp.671-688.

Rosensweig. R. E., Ferrohydrodynamics (1985), pp.1-344, Cambridge University Press.

Sudo, S., Asano, D., Takana, H. and Nishiyama, H., Alternating magnetic field response of magnetic fluid drop adsorbed to a small permanent magnet, Materials Science Forum, Vol.721 (2012b), pp.102-107.

Sudo, S., Goto, T., Yano, T., Futamura, M., Takana, H. and Nishiyama, H., Micro reciprocating actuator using magnetic field and two permanent magnets, Journal of Solid Mechanics and Material Engineering, Vol.6 (2012a), pp.555-564.

Sudo, S., Hashimoto, H. and Ikeda, A., Measurements of the surface tension of a magnetic fluid and interfacial phenomena, JSME International Journal, Vol.32, No.1 (1989), pp.47-51.

Sudo, S., Hashimoto, H. and Katagiri, K., Interfacial instability of magnetic fluids in a rectangular container, JSME International Journal, Vol.30, No.265 (1987), pp.1086-1092.

Sudo, S., Ohaba, M., Katagiri, K. and Hashimoto, H., Dynamic behavior of magnetic liquid drop on a solid base subject to magnetic field and vertical vibration, Journal of Magnetism and Magnetic Materials, Vol.122 (1993), pp.248-253.

Sudo, S., Takaki, Y., Hashiguchi, Y. and Nishiyama, H., Magnetic fluid devices for driving micro machines, JSME International Journal, Vol.48, No.3 (2005), pp.464-470.

Sudo, S., Yano, T., Okabe, M. and Komatsu, T., A study of micro magnetic fluid actuator, International Journal of Applied Electromagnetic and Mechanics, Vol.25 (2007), pp.95-101. 